\title{
CORRESPONDENCE
}

The American Journal of International Law welcomes short communications from its readers. It reserves the right to determine which letters shall be published and to edit any letters printed.

TO THE EDITOR-IN-CHUEF:

March 23, 1977

The October 1976 issue of the Journal contains a note on the use of the Jessup International Law Moot Court Cases in Political Science Departments. ${ }^{1}$ I should like to give you a brief report on the use I have made of them at Tulane Law School.

In conducting seminars in International Law in the past, I have usually required the writing of papers and those as a rule turned out to be what one might call "research" papers. One difficulty with the format is that the papers tend to vary considerably in length and depth of research, which makes it difficult to work out a fair system of grading. In the fall semester of the academic year 1976-1977, it occurred to me I could use for a seminar of twelve students the cases prepared over the years for the Jessup International Law Moot Court Competition. I wrote the Society and was supplied within a short time with a number of the previous cases, as well as a copy of the official rules for the Competition. ${ }^{2}$

The students were divided into six groups of two. Each group was assigned a different case and required to write two briefs, one on each side of the case. The two students in each group could and were indeed invited to collaborate with each other in the research and discussion of the issues, but each was responsible for the writing of his own brief and was graded on it.

It turned out to be a very successful format. In my opinion, the success was due essentially to the element of adversary advocacy in the format. When research papers were the rule in previous years, this element was, of course, missing. In using the cases, I could get the members of each group to argue their side of the case within two-hour sessions, with some time being left for questions and for appraisal by me.

Because the participants were all subject to the rules of the competition, including the limitations on the number of pages, a degree of evenhandedness was introduced in the grading which did not exist when research papers were required. On the other hand, the use of the moot court cases introduces a new variable because the cases differ in degrees and kinds of difficulty. In some cases, for example, the facts are complicated but the legal issues quite traditional, which means a wealth of authorities is available and the main challenge in writing the briefs is to compress the arguments. In other cases, the facts are relatively simple but the issues novel,

1 Collins, The Use of Jessup International Law Moot Court Cases in Political Science Departments, 70 AJIL 809 (1976).

2 Jessup materials are made available at nominal cost. For information write: Association of Student International Law Societies, 2223 Massachusetts Ave. N.W., Washington, D.C. 20008. 
so there are not many authorities available and much of the challenge lies in ingenuity of reasoning.

I certainly intend to use the cases again and thought the Society, as well as Judge Jessup, might be interested in hearing of the uses to which they have been put in at least this law school.

Joseph MODESTE SWEeney Tulane Law School

\section{TO THE EDITOR-IN-ChIEF}

February 14, 1977

I would like to respond to the letter of Mr. Perry Pickert who commented on my article in the July 1976 issue of the Journal. ${ }^{1}$ Referring to Article 26 of the Treaty of Peace with Japan of September $8,1951,{ }^{2}$ he asserted that "even today, Japan lives under the threat of a unilateral unconditional mostfavored-nation clause." 3 Such an assertion is quite misleading and stands in the way of a proper understanding of the problem I tried to describe, for it ignores the actual situation of Japan under the Peace Treaty.

First, while I spoke of the "historical significance" of the unilateral clause as the typical pattern of treaty provision concluded in certain relationships between states until the 19th century, I never stated, and had no intention of implying, that such a clause is nonexistent today. Such an implication is contradicted by the remainder of my article. I am fully aware that similar clauses still exist under exceptional circumstances (such as navigation provisions in a treaty concluded with a landlocked state and certain peace-settlement provisions imposed upon the defeated in peace treaties). However, these examples cannot legitimately be construed as the typical treaty practice, the characteristics of which I described in the first paragraph of my article and footnotes 1 to 3 .

Moreover, it should be noted that the second sentence of Article 26 of the Peace Treaty quoted by Mr. Pickert has substantially lost its operative effect since the conclusion of the Joint Declaration with the Soviet Union of October 19, $1956^{4}$ and the Joint Communiqué with the People's Republic of China of September $29,1975^{5}$ (which replaced the Treaty of Peace with the Republic of China of April 28, 1952 ${ }^{\circ}$ ), in both of which peace has been restored and war claims have been waived, even though they are not peace treaties in form. In other words, the said provision now bears no practical significance and the application thereof is realistically inconceivable. After a dozen decades since Commodore Perry, it seems obvious that the change in the international environment has been so fundamental that one cannot compare that era with the present simply by pointing out the formal existence of a similar treaty provision.

Shinya Murase

To The EdTor-IN-ChieF

April 26, 1977

The piercing eye and pointed pen of the very erudite Prof. Julius Stone could find nothing useful in the consensus definition of aggression. ${ }^{1}$ His criticism of the defects and deficiencies are well taken but at the risk of

\footnotetext{
1 The Most-Favored-Nation Treatment in Japan's Treaty Practice During the Period 1854-1905, 70 AJIL 273 (1976).

23 UST 3169, TIAS No. 2490, 136 UNTS 45, at 75.

370 AJIL 816 (1976). 4263 UNTS 99.

517 The Japanese Annual of International Law 81 (1973).

6138 UNTS 3.

${ }^{1}$ Hopes and Loopholes in the 1974 Definition of Aggression, 71 AJIL 224 (1977).
} 